University of Nebraska - Lincoln

DigitalCommons@University of Nebraska - Lincoln

Faculty Publications: Department of

Entomology

Entomology, Department of

2021

A NEW SUBSPECIES OF LON TAXILES (W. H. EDWARDS, 1861)
(LEPIDOPTERA: HESPERIIDAE) FROM THE GREAT PLAINS

Stephen M. Spomer

Follow this and additional works at: https://digitalcommons.unl.edu/entomologyfacpub

Part of the Entomology Commons

This Article is brought to you for free and open access by the Entomology, Department of at

DigitalCommons@University of Nebraska - Lincoln. It has been accepted for inclusion in Faculty Publications:

Department of Entomology by an authorized administrator of DigitalCommons@University of Nebraska - Lincoln. 


\title{
A NEW SUBSPECIES OF LON TAXILES (W. H. EDWARDS, 1861) (LEPIDOPTERA: HESPERIIDAE) FROM THE GREAT PLAINS
}

\author{
STEPHEN M. SPOMER \\ Department of Entomology, University of Nebraska, Lincoln, NE 68583-0816 \\ Email: sspomer1@unl.edu
}

\begin{abstract}
A new subspecies of Lon taxiles (W. H. Edwards, 1861) is described from the Pine Ridge of Nebraska and Black Hills of South Dakota. It is distinguished by the presence of distinct white spots on the VHW of females and darker males than specimens from other parts of its range.
\end{abstract}

Additional key words: Black Hills, Pine Ridge, North Dakota Badlands

The Taxiles skipper, Lon [formerly Poanes; see Cong et al. (2019)] taxiles (W. H. Edwards, 1861), is a woodland species found in mountainous areas in extreme southeastern Idaho, through Colorado and Utah, south through New Mexico and Arizona, into Mexico. There is also a somewhat disjunct eastern population, ranging from the Pine Ridge of Nebraska, eastern Wyoming, into the Black Hills of South Dakota, north to the Badlands of North Dakota. Most western populations are fairly consistent in phenotype, and the sexes are dimorphic. Males are orange and black dorsally and yellow with brown spotting ventrally, while females are brownish dorsally with a purplish-brown ventral hindwing. Both sexes resemble Lon zabulon (Boisduval \& Le Conte, [1837]), at least ventrally, and are considered the western counterpart of that species.

While collecting in the Pine Ridge and Black Hills in the early 1980s, I noticed that the phenotype there was distinct from the more western populations. Instead of having the spotting on the ventral hind wing of females obscured as in other areas, these specimens had distinct white spotting. I was intrigued, so decided to examine specimens from nearby eastern Wyoming, as well as more specimens from Nebraska and South Dakota, and compare these with typical populations from the Rocky Mountains and other western mountain ranges. This led me to describe a new taxon:

\section{Lon taxiles albimaculatus Spomer ssp. nov.}

Description. Size: FW length averages $1.61 \mathrm{~cm}$ $(\mathrm{SD}=0.05, \mathrm{n}=49)$ in males and $1.67 \mathrm{~cm}(\mathrm{SD}=0.06$, $\mathrm{n}=35$ ) in females.

Facies: As is typical in hesperiids, females are larger, with broader and more rounded wings than males.

Males are orange dorsally, with dark brown to black borders. At the end of the FW cell, there is a thin black dash with a small patch of black scales above it. In cell $\mathbf{M}_{1}$, there is usually a patch of black scales inside the dark border. There is black scaling at the base of the FW. Ventrally, the FW is orange with a brown border and a large patch of black scales at the base. The VHW is brown with a large yellow patch containing brown spots in veins $\mathrm{CuA}_{2}, \mathrm{CuA}_{1}$, and $\mathrm{M}_{3}$. There is an irregular brown patch encompassing the cell and several other veins, with a yellow patch at the base.

Females are dark brown and orange dorsally. Orange scaling varies from being restricted to the postmedian bands to reaching the base of the wings, although all females show dark scaling at the base. The VFW is orange with thick dark borders and a large elongated patch of black scales basally. The VHW is brown with white spots in the postmedian and submedian bands. These white spots vary from slightly distinct to very distinct. On fresh specimens, the VHW shows a violet tint, but this fades to brown on worn specimens.

A large series of adults reveals some individual variation in dorsal and ventral ground color of both sexes, distinctiveness of VHW spots in the female, and width of the DFW black border in the males.

Larval foodplant: Scott (1975) lists the broadleaf grasses Puccinellia nuttalliana (Schult.) Hitchc., Poa pratensis L., Agropyron repens (L.), A. smithii Rydb., A. trachycaulus (Link) Gould ex Shinners, Dactylis glomerata L., Elymus canadensis L., and Agrostis gigantea Roth. M. Brust (pers. comm.) ob-

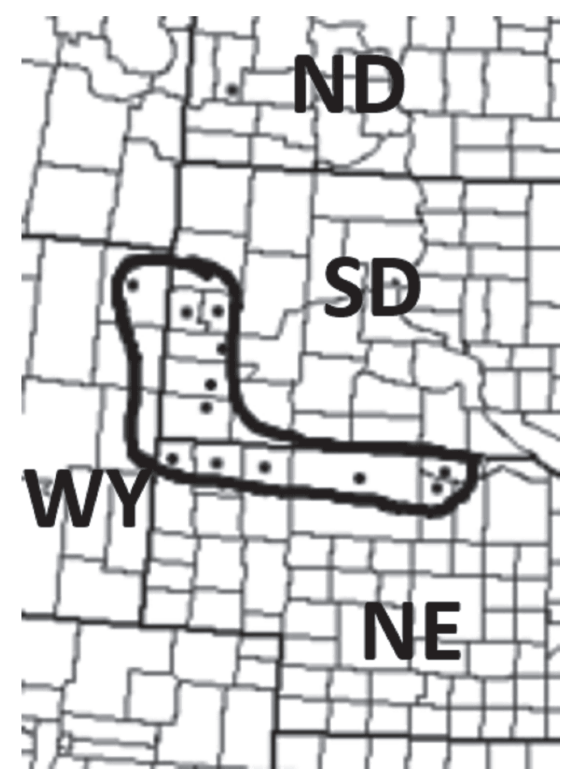

FIG. 1. Distribution of Lon taxiles albimaculatus in the Great Plains. 


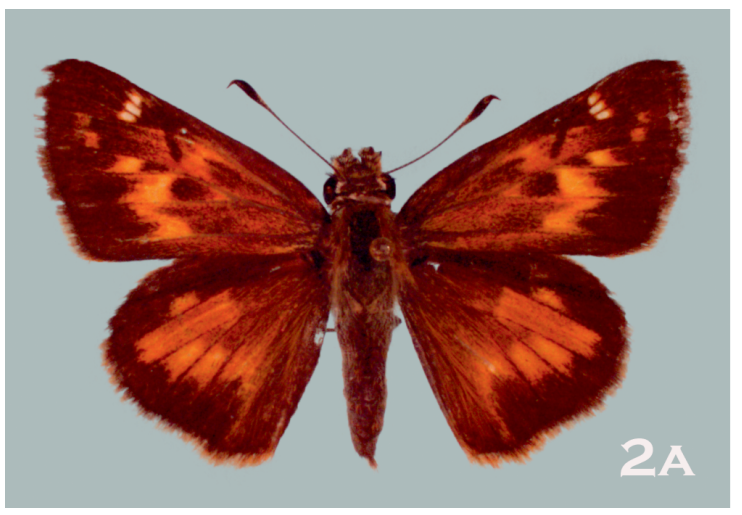

FIG. 2. Holotype female of Lon taxiles albimaculatus.

served oviposition on Bromus inermis Leyss. in Nebraska, with Elymus sp. in close proximity. I have also reared larvae on Bromus inermis, as well as Muhlenbergia schreberi J. F. Gmel. Larvae refused Eleusine indica (L.) Gaertn.

Generations per year: this skipper is univoltine, with adults appearing in early- to late-July. Larvae reared in the lab under constant light will emerge in ca. 100 days.

Range and habitat: this subspecies is known from Sioux, Dawes, Sheridan, Cherry, Keya Paha, and Brown Cos. in Nebraska, and Marrone (2002) shows Fall River, Custer, Pennington, Lawrence, and Meade Cos. in South Dakota. A 2020 record of this subspecies appears on iNaturalist (2021), along with a photo of a female from Billings Co. North Dakota. This represents a significant range extension for this butterfly. The BAMONA website (2021) shows a distributional dot south of Devil's Tower (Black Hills NF, Crook Co. Wyoming) that is probably this subspecies, but two females in the AMNH collection from the Casper Mtns. (Natrona Co. WY) appear to be intermediate between the new subspecies and specimens from the Rocky Mountains. Fig. 1 shows the known distribution of the new subspecies. Adults are found along creeks and wet areas. Adults have been seen taking nectar from vervain, Verbena spp., beebalm, Monarda spp., and catnip, Nepeta cataria L.

Type material. Holotype: female (Fig. 2). NE: Sioux Co., Sow Belly Canyon, Coffee Park, 27 July 1989, leg. S.M.Spomer. FW length $1.8 \mathrm{~cm}$. To be deposited in AMNH.

Allotype: male (Fig. 3). SD: Fall River Co., Hot Brook Cr., 3500', NW edge of Hot Springs, 28 June 1994, coll. by K. Roever. FW length $1.6 \mathrm{~cm}$. To be deposited in AMNH.

Paratypes (Fig. 4): 14 Males: 1 (10 $)$ SD: Fall River Co., Hot Brook Cr., 3500', NW edge of Hot Springs, 27 June 1994,

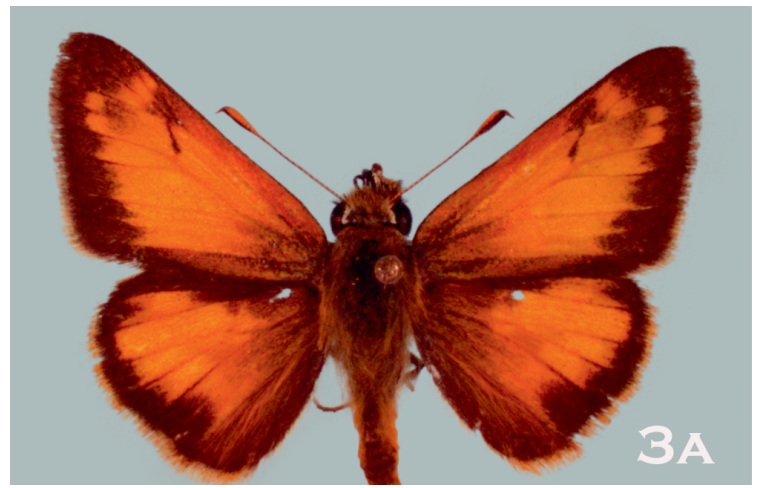

FIG. 3. Allotype male of Lon taxiles albimaculatus.

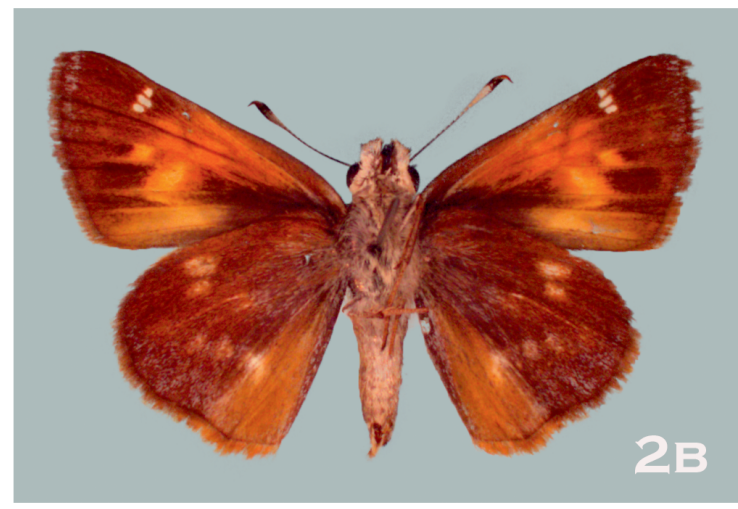

coll by K. Roever; $3\left(3 \hat{\delta}^{\hat{}}\right)$ same data as previous except 28 June 1994; 1 (10 ) NE: Dawes Co., East Ash Creek, 42-4400', Pine Ridge, 20 June 1996, coll. by K. Roever; 2 (20') NE: Sioux Co., Sowbelly Cyn., Coffee Park, along creek, 11 July 2004, leg. S. M. Spomer; $2\left(20^{\hat{C}}\right)$ same data as previous except 1 Aug. 2002; 1 (10 ) NE: Sioux Co., Monroe Cyn., ex-ovum, (+) 25 July 2018, em. 27 Oct. 2018, leg. S. M. Spomer, reared on Muhlenbergia schreberi by S. M. Spomer; 1 (10) NE: Dawes Co., ca. 8.0 mi. S of Chadron, Chadron State Park, July 27 2011, coll. M. L. Brust; 1 (1ठㅅ) War Bonnet Cyn. (Sioux Co. NE), 6/27/11 (1911), R. W. Dawson; 1 (10') NE: Sioux Co., Sowbelly Cyn., Coffee Park, along creek, ex-ovum, (क) coll. 11 July 2004, em. 15 Oct.-3 Nov. 2004, reared on Bromus inermis by S. M. Spomer; $1\left(10^{\hat{A}}\right)$ NE: Dawes Co., King Canyon, 10 July 2020, leg. S. M. Spomer. 14 Females: 1 (19) SD: Fall River Co., Hot Brook Creek., 3500', NW edge of Hot Springs, 27 June 1994, coll. by K. Roever; 1 (19) NE: Dawes Co., ca. 8.0 mi. S of Chadron, Chadron State Park, July 26 2011, coll. M. L. Brust; 1 (19) same data as previous specimen, except July 27 2011; 1 (19) NE: Dawes Co., Chadron State Park, 2 July 1986, J. M. Reiser; 1 (19) NE: Sioux Co., Sow Belly Canyon, Coffee Park, 6 July 1991, leg. S. M. Spomer; 1 (19) SD: Custer Co., Iron Cr., nr. Dakota Lake, 8 July 1989, G. M. Marrone; 2 (29) NE: Sioux Co., Sowbelly Cyn., Coffee Park, along creek, ex-ovum coll. 11 July 2004, em. 15 Oct.- 3 Nov. 2004, reared on Bromus inermis by S. M. Spomer; 1 (19) NE: Sioux Co., Monroe Cyn., 15 July 2014, coll. M. L. Brust; 1 (19) NE: Sioux Co., Sowbelly Cyn., Coffee Park, along creek, 11 July 2004, leg. S. M. Spomer; 1 (19) NE: Dawes Co., Chadron State Park, 4 July 2015, coll. M. L. Brust; 1 (1ㅇ) NE: Sioux Co., Monroe Cyn., ex-ovum, (ㅇ) 25 July 2018, em. 22 Oct. 2018, leg. S. M. Spomer, reared on Muh-

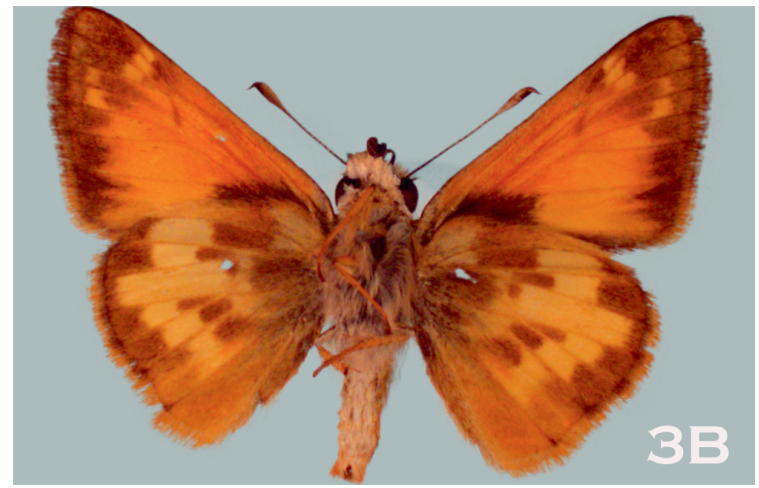




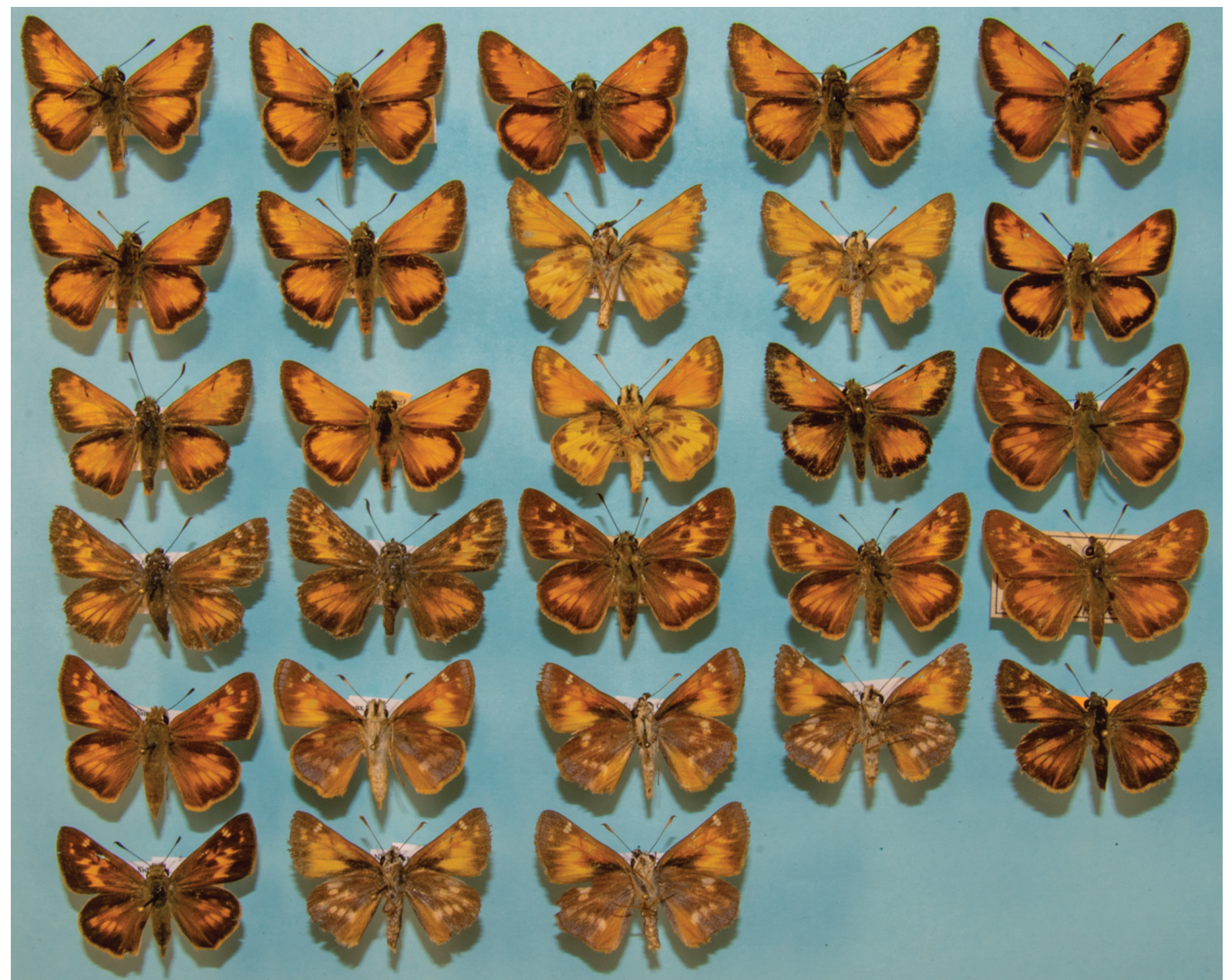

FIG. 4. Paratypes of Lon taxiles albimaculatus. Data for specimens corresponds to order shown in manuscript starting with top row, upper left.

lenbergia schreberi by S. M. Spomer; 2 (2\%) NE: Sioux Co., Monroe Cyn., 25 July 2018, leg. S. M. Spomer. To be deposited in AMNH, University of Nebraska State Museum, South Dakota State Museum, Colorado State Museum, and various private collections.

Etymology: in Latin, the name means white spots, which refers to the distinct white spots on the ventral HW of the female.

Diagnosis. Females are the distinguishing sex for this subspecies, exhibiting white spots on the VHW that range from moderately to extremely prominent in $80 \%$ of the specimens. Males cannot be reliably distinguished from those from other areas except Utah (Utah males are lighter, with thinner black borders), although in a long series the VHW has a darker ground color than those from the Rocky Mountains.

\section{DisCUSSION}

In a series, females of the new subspecies are dorsally darker than Rocky Mountain females, but only slightly darker than Arizona females. Two specimens examined had the VHW spots obscured, and two specimens had spots only slightly prominent. All other females ranged from moderately to extremely prominently spotted. Colorado and New Mexico females ranged from completely obscured to only slightly prominent. Arizona females were similar to Rocky Mountain females, although one female from the Pinaleno Mtns. (Graham Co.), one female from the Chiracahua Mtns. (Cochise Co.), and one female from Coconino Co. had moderately prominent spots. Of four females from Mexico (Durango and Chihuahua states), three had completely obscured spots while one had only slightly prominent spots, although dark dorsally, like the new subspecies. Pelham (2021) shows typical Colorado and Arizona adults, as well as a pair from Sonora, MEX. Marrone (2002) shows a pair of the new subspecies from Iron Creek, Custer Co., South Dakota.

Males of the new subspecies are similar to Rocky Mountain males dorsally, but ventrally are similar to males found in Arizona, darker than Rocky Mountain 
males, and much darker than Utah males. Dorsally, the spot above the stigma is obvious on most males of the new ssp., rarely found on Rocky Mountain males. The dark spot in cell $\mathrm{M}_{1}$ is seen on about half of the males from SD/NE/AZ, on almost none of the Rocky Mountain males, and zero of the UT males.

Another interesting population of L. taxiles occurs in UT. Both sexes are lighter compared to those examined from anywhere else, and females have somewhat prominent yellow, not white, spots on the VHW. This population is currently under investigation.

\section{Conservation}

This subspecies seems to be disappearing throughout its limited range. Sowbelly Canyon burned in 2006, and the colony along Sowbelly Creek in Coffee Park (TL) has not been seen since. East Ash Creek also burned in 2012, and that population (along with Phyciodes batesii lakota Scott, 1994) has not been seen since the fire. Two colonies that still remain consistent are at Chadron State Park (Dawes Co. NE) and Gilbert-Baker WMA (a.k.a Monroe Canyon) (Sioux Co. NE), but collectors should not overcollect from these sites. Once ranging as far east as the Niobrara Valley Preserve (Keya Paha, Brown Cos.) in Nebraska, it has not been seen there since 2006 (N. Dankert, pers. comm.). It is unknown how the colonies in the Black Hills are doing, but I have stopped at Hot Brook Creek within the last six years and was unable to find any. Additonally, when I surveyed the Black Hills for Speyeria atlantis pahasapa Spomer, Scott, \& Kondla,1998, in July and August of 2004, I did not see a single specimen of L taxiles.

Perhaps the recent drought conditions in the northern Plains, coupled with fires has led to the disappearance of this species, but this is speculative.
MATERIAL EXAMINED ( $\mathrm{n}=263$ ) (State, County)

NM: Bernalillo, Colfax, Sandoval, Catron, Union, Torrance

CO: Boulder, Larimer, El Paso, Archuleta

UT: Davis, Kane, Garfield, Juab, Iron

AZ: Cochise, Graham, Apache, Coconino, Gila, Santa Cruz, Greenlee

WY: Natrona

NE: Sioux, Dawes, Keya Paha, Brown, Cherry

SD: Custer, Fall River, Pennington

MEX: Durango, Chihuahua States

\section{ACKNOWLEDGMENTS}

A huge thanks goes out to Mathew Brust, who supplied enough adults for this study to be possible and accompanied me on several trips to the Black Hills. Gary Marrone was very helpful in providing localities within the Black Hills. Jim Reiser and Neil Dankert supplied specimens, and Neil was instrumental in finding specimens at the Niobrara Valley Preserve. Todd Stout supplied specimens of the UT population, and Kilian Roever supplied many specimens from many localities. Access to specimens at the University of Nebraska State Museum was made possible by Brett Ratcliffe. I also wish to thank the AMNH for their loan of specimens. Paul Opler, Todd Stout, and Mike Fisher looked at earlier drafts and made helpful comments, as did the two anonymous reviewers.

\section{Literature Cited}

BAMONA. 2021. Available from https://www.butterfliesandmoths.org/ species/Poanes-taxiles (accessed April 27, 2021).

Cong, Q., J. Zhang, J. Shen, and N. V. Grishin. 2019. Fifty new genera of Hesperiidae (Lepidoptera). Insecta Mundi 0731: 1-56.

INATURALIST. 2021. Available from http://inaturalist.org/ observations/53872849 (accessed April 27, 2021).

Marrone, G. M. 2006. Field guide to the butterflies of South Dakota. South Dakota Dept. Fish, Game, and Parks. 478 pp.

Pelham, J. P. 2021. A catalogue of the butterflies of the United States and Canada. Available from http://www.butterfliesofamerica.com/ US-Can-Cat.htm (accessed April 27, 2021).

SсотT, J. A. 1975. The butterflies of North America: a natural history and field guide. Stanford University Press, Stanford, CA. 583 pp.

Submitted for publication 30 October 2020; revised and accepted 10 December 2020. 